\title{
Membaca Hambatan Implementasi Pariwisata Halal Bangkalan
}

\author{
Khoirun Nasik \\ Dosen Hukum Bisnis Syariah, Universitas Trunojoyo Madura \\ nasik.gresik@gmail.com
}

DOI: https://doi.org/10.21107/dinar.v5i1.5124

\begin{abstract}
Abstrak
Kemajuan zaman dan meningkatnya kesejahteraan masyarakat di era modern akan mempengarubi pertumbuhan bisnis. Diantara bisnis tersebut adalab sektor pariwisata syariab sebagai jawaban atas kebutuban batiniyah. Data kementerian pariwisata menunjukkan bahwa bisnis syariah termasuk sek.tor pariwisata di Indonesia mengalami peningkatan pengunjung cukup signifikan.

Kabupaten Bangkalan bagian dari pulau Madura terkenal dengan budaya religius dan memiliki potensi destinasi yang indah. Destinasi diantaranya adalah : wisata alam seperti bukit Jaddih, kapur Arosbaya, pantai rongkang, Sembilangan. wisata kuliner terdiri dari bebek sinjay, matus, nasi serpang, wisata religi antara lain makam syaikhona Mubammad Kholil, Sultan abdul Kadirun, Ratu Ibu. wisata sejarah, sentra batik, wisata budaya dan wisata bahari.

Namun penerapan dan pengelolaan pariwisata syariah belum nampak. Hal ini tentu ada faktor yang menjadi penyebab. Tujuan dari tulisan ini adalah untuk mengetahui faktor penghambat implementasi pariwisata syariah di Bangkalan sekaligus berupaya menemukan solusi praktis menyelesaikannya mengingat Madura memiliki potensi yang cukup besar. Untuk metode penelitian, artikel ini menggunakan pendekatan kualitatif dengan jenis penelitian studi literature.

Hasil penelitian menunjukan beberapa hal yang menjadi hambatana antara lain : kurangnya kerjasama antara pibak, pergantian jabatan, minimnya anggaran, belum ada destinasi andalan, objek wisata milik perorangan, belum ada regulasi detil dari kementerian pariwisata. .
\end{abstract}

Kata Kunci : Faktor penghambat, Pariwisata syariah. 


\section{Pendahuluan}

Kemajuan zaman dan meningkatnya kesejahteraan masyarakat di era modern akan mempengaruhi pertumbuhan bisnis. Sesuatu yang dulu tidak dianggap bisnis, seiring perkembangan zaman dan kesejahteraan masyarakat, akan berpotensi menjadi bisnis ${ }^{1}$.

Indonesia adalah negara dengan jumlah penduduk muslim cukup besar, dengan spirit religius cukup tinggi, dan dengan kekayaan sumber daya alam yang melimpah akan menjadi modal potensi bisnis yang besar jika dikembangkan dengan baik.

Spirit religiusitas (semangat keberagamaan) umat Islam di Indonesia, akan menyulut perubahan gaya hidup. Apalagi didukung dengan meningkatnya kesejahteraan materi, akan mendorong akselerasi dalam mobilitas sosial.

Menyatunya gaya hidup dan tersedianya kesejahteraan materi akan mempengaruhi meningkatnya kebutuhan baik yang bersifat lahiriyah maupun bersifat batiniyah. Kebutuhan lahiriyah berkaitan dengan materi seperti rumah, mobil, alat komunikasi dan perhiasan. Kebutuhan bersifat batiniyah berkaitan dengan kepuasan dan ketentraman hati2.

Berkaitan dengan kebutuhan bersifat batiniyah, bisnis syari'ah menjadi pilihan menarik karena dianggap mampu mengakomodir dua kebutuhan sekaligus, kepuasan lahir dan batin sehingga jumlah peminat mengalami peningkatan. Data kementerian pariwisata menunjukkan bahwa bisnis berbasis syari'ah mngalami peningkatan yang signifikan. pertama, warda cosmetic meningkat rata rata $75 \%$ pertahun dalam 4 tahun terakhir, padahal menurut AC nelsen rata rata industry hanya naik 15\%. Kedua, Sofyan Hotel syari'ah meningkat 15$20 \%$ pertahun. Ketiga, Bakmi gajah mada, KFC, Hoka bento memantapkan perkembangan usahanya dengan sertifikisasi halal LP POM MUI. Keempat, Ditjen kemenparekraf mencatat kunjungan wisatawan Muslim ke Indonesia mencapai 1.270.437 mayoritas dari Arab Saudi, Bahrain, Malaysia, Singapura, dan Perancis

Untuk mengakomodir keduanya, diperlukan suatu model tempat hiburan dan sarana rekreasi alternatif yang tidak semata-mata memenuhi kebutuhan lahiriyah semata, tetapi juga mampu menyentuh dimensi batin dan spiritual, sehingga wisata tersebut benar-benar memberi hiburan yang bisa memuaskan secara lahir batin. Dalam kontek inilah Pariwisata Syari'ah bisa menjadi alternatif untuk menjawab kebutuhan tersebut.

Dengan demikian, nilai-nilai Islam mampu memberi warna dalam semua aspek termasuk aspek pariwisata dengan sentuhan yang humanis sesuai dengan kaidah-kaidah

\footnotetext{
${ }^{1}$ Salon rambut, kecantikan, pelayanan jasa pengembangan SDM, Travel dan pariwisata adalah sebagian contoh bisnis yang tumbuh mengikuti perkembangan zaman. Dulu semua itu bukan bisnis, namun sekarang menjadi bisnis profit.

${ }_{2}^{2}$ https://travel.kompas.com/read/2013/08/15/1825544/Indonesia.Kembangkan.Pariwisata.Syariah. Dan lihat juga Sofyan ketua Percepatan Pariwisata Syari'ah kemenparkraf, Implementasi Pariwisata Syari'ah, disampaikan di Unipdu Jombang 19 Oktober 2013
} 


\section{Minar}

Eurnal \& konomi \& Qeuangan @slam

https://journal.trunojoyo.ac.id/dinar/index

DOI: https://doi.org/10.21107/dinar
Dinar. Vol 6, No 2: Agustus 2019.11-21

ISSN: 2460-9889 (Cetak)

ISSN: 2580-3565 (Online)

syar'iyah yang melindungi hak dan kebutuhan dasar hidup manusia (perlindungan terhadap keimanan, kehidupan, akal, keturunan, dan ekonomi/harta benda).

Secara tersirat banyak ayat al qur'an yang membahas tentang pariwisata yakni perintah menjelalahi bumi agar manusia mendapat banyak pelajaran. Di antaranya adalah firman Allah SW'T itu adalah:

"Sunggub telab berlalu sebelum kamu sunnah-sunnah Allab; Karena itu berjalanlah kamu di muka bumi dan perbatikanlah bagaimana akibat orang-orang yang mendustakan (rasul-rasul)" (Ali Imran 137);

"Katakanlah: Berjalanlah di (muka) bumi, maka perhatikanlah bagaimana Allah menciptakan (manusia) dari permulaannya, kemudian Allah menjadikannya sekali lagi. Sunggub Allah Maha Kuasa atas segala sesuatu" (al-Ankabut 20); "Dialah Yang menjadikan bumi itu mudah bagi kamu, maka berjalanlah di segala penjurunya dan makanlah sebahagian dari rezki-Nya. Dan hanya kepada-Nya-lab kamu (kembali setelab) dibangkitkan" (al-Mulk 15); dan masih banyak ayat-ayat semakna lainnya.

Nabi Ibrahim juga melakukan perjalanan dari Makkah ke Palestina, Nabi Musa juga pergi dari Mesir ke Madyan, Rasulullah SAW juga melakukan perjalanan isra' dari Masjidilharam ke Masjidilaqsha, mendapat perintah hijrah dari Makkah ke Madinah, 4 kali melakukan perjalanan umrah dari Madinah ke Makkah, 1 kali menunaikan ibadah haji, bahkan ibadah haji merupakan salah satu dari 5 rukun Islam. Itu semua dapat dipahami, bahwa Islam mengisyaratkan, menegaskan, mengajarkan, bahkan memerintahkan umatnya untuk banyak melakukan perjalanan, wisata, traveling guna mendapatkan refreshing dan pelajaran moral-spiritual.

Jadi pariwisata itu mendapat perhatian penting dari ajaran Islam, yang tentunya dapat menjadi lahan aktifitas ibadah yang luar biasa dan memiliki potensi pahala yang amat besar, asal kita bisa menata hati, meluruskan niat, mengelola kepariwisataan, dan membenahi tempat-tempat wisata agar sedapat mungkin terhindar dari segala jenis kemaksiatan (Zahro, 2013).

\section{Tinjauan Pustaka}

\section{Faktor Penghambat}

Dalam Kamus Besar Bahasa Indonesia, kata faktor diartikan sebagai berikut: 1) Keadaan, hal atau peristiwa yang ikut mempengaruhi atau menyebabkan terjadinya sesuatu. 2) Matematika diartikan sebagai bulangan atau pun bangunan yang adalah hasil dari perbanyakan. Sementara arti dari penghambat adalah sesuatu yang sifatnya menghambat. Hambat sendiri maksudnya adala membuat sesuatu hal bisa perjalanan, pekerjaan dan semacamnya menjadi tidak lancar, lambat atau tertahan. Adapun yang dimaksud dengan 
faktor penghambat adalah semua jenis faktor yang sifatnya menghambat (menjadikan lambat) atau bahkan menghalangi dan menahan terjadinya sesuatu.

\section{Pariwisata}

Istilah tourism pariwisata muncul di masyarakat abad ke-18, khususnya sesudah Revolusi Industri di Inggris Istilah Pariwisata berasal dari dilaksanakannya kegiatan wisata atau tour yaitu sesuatu aktivitas perubahan tempat tinggal sementara seseorang. Istilah pariwisata diperkenalkan pertama kali di Indonesia pada saat Musyawarah Nasional Yayasan TourismeIndenesia ke-II atau usul dari presiden pertama Ir. Soekarno dan akhirnya pada 1961 istilah dipakai resmi untuk menggantikan istilah tourisme (Muljadi \& Warman, 2016: 07).

Pariwisata merupakan keseluruhan hubungan dan gejala-gejala yang timbul dari adanya orang asing dimana perjalanannya tidak untuk bertempat tinggal menetapkan dan tidak ada hubungan dengan kegiatan untuk mencari nafkah (Muljadi \& Warman, 2016: 09).

Menurut Undang-Undang Republik Indonesia Nomor 9 Tahun 1990 tentang Kepariwisataan, bahwa pengertian pariwisata adalah segala sesuatu yang berhubungan dengan wisata termasuk pengusahaan objek dan daya tarik wisata serta usaha-usaha yang tertarik di bidang ini. Sedangkan dalam Undang-Undang Republik Indonesia Nomor 10 Tahun 2009 tentang kepariwisataan, memberikan pengertian bahwa pariwisata adalah berbagai macam kegiatan wisata dan didukung berbagai fasilitas serta layanan yang disediakan oleh masyarakat, pengusaha, pemerintah, dan pemerintah daerah.

Sedangkan pengertian pariwisata syariah bisa didefinisikan sebagai suatu kegiatan wisata yang didukung dengan berbagai fasilitas serta layanan yang sesuai dengan prinsip Syariah. Adapun yang dimaksud dengan prinsip syariah adalah prinsip hukum Islam terkait berbagai kegiatan pariwisata berdasarkan fatwa yang dikeluarkan oleh lembaga yang berwenang. Di Indonesia lembaga dimaksud adalah Dewan Syariah Nasional Majelis Ulama Indonesia (DSN-MUI).

1) Jenis Pariwisata

Terdapat berbagai jenis pariwisata yang dikelompokkan berdasarkan tujuan atau motif seseorang atau kelompok yang melakukan perjalanan wisata berikut jenis-jenis pariwisata: Pertama pariwisata untuk menikmati perjalanan (Pleasure Tourism). Jenis pariwisata ini dilakukan oleh orang-orang yang meninggalkan tempat tinggalnya untuk berlibur, untuk menikmati keindahan alam, atau untukmendapatkan ketenangan dan kedamaian di daerah kota.

Kedua, pariwisata untuk Rekreasi (Recreation Tourism). Jenis pariwisata ini dilakukan oleh orang-orang yang menghendaki pemanfaat hari liburnya untuk istirahan dan menyegarkan kembali kesegaran jasmani dan rohani akibat terlalu banyak bekerja. Ketiga, Pariwisata untuk Kebudayaan (Cultural Tourism). Jenis pariwisata ini dilakukan karena adanya keinginan untuk mempelajari adat istiadat, kelembagaan dan cara hidup rakyat daerah lain 


\section{Minar}

selain itu untuk mengunjungi momentum bersejarah,peninggalan peradaban masa lalu, pusat-pusat kesenian, pusat-pusat keagamaan, atau untuk ikut serta dalam festival-festival seni musik, teater, tarian rakyat, dll.

2) Destinasi Wisata

Menurut Kamus Besar Bahasa Indonesia, Destinasi merupakan tempat atau tujuan,di mana inti dari produk pariwisata adalah destinasi wisata yang menjadi daya tarik utama dalam perkembangan industri pariwisata dan mempunyai keunggulan dan ciri khas, baik secara geografis maupun budaya sehingga dapat menarik wisatawan untuk mengunjungi dan menikmatinya.

Destinasi Wisata merupakan daerah yang ideal untuk mengevaluasi jaringan inovasi antar perusahaan karena dua alasan pertama organisasi di destinasi pariwisata sangat berjenjang sampai pada tingkat tujuan. dapat dipahami sebagai "kelompok pemasok independen yang digabungkan secara longgar yang terkait untuk memberikan keseluruhan produk, selama bertahun-tahun, destinasi telah semakin berjenjang sebagai respons terhadap harapan wisatawan akan sebuah pengalaman menyeluruh daripada serangkaian pertukaran terpisah (Prasetyo \& Arifin, 2018: 04).

3) Cara Mengoptimalisasi Pariwisata

Menurut Muljadi \& Warman (2016) salah satu pengoptimalan pariwisata di suatu daerah agar dapat dikenal oleh masyarakat luas antara lain dapat menggunakan beberapa cara antara lain:

a. Pengadaan Perencanaan Paket Wisata

Paket wisata sendiri dapat diartikan sebagai suatu program perjalanan wisata dengan beberapa tujuan wisata yang tersusun dari berbagai fasilitas jasa perjalanan tertentu yang tersusun berdasarkan jadwal acara yang telah ditetapkan.

Paket wisata merupakan produk pariwisata yang direncanakan oleh seorang petugas perencana pariwisata atau tourplanner. Seorang petugas perencanaan harus menguasai dan paham tentang berbagai aspek yang berkaitan dengan kegiatan wisata, salah satunya adalah dengan menyediakan fasilitas pendukung perjalanan yang dapat memberikan pemenuhan kebutuhan dalam perjalanan wisata para wisatawan saat berkunjung. Segala sesuatu itu harus tersedia pada daerah tujuan sebagai salah satu daya tarik wisatawan dan pertimbangan mereka ketika hendak berkunjung. Komponen-komponen paket pariwisata yang dapat dirancang meliputi: Jasa transportasi baik darat, laut, maupun udara, Jasa penginapan, Jasa penyajian makanan dan minuman, Jasa daa tarik wisata, rekreasi, seni budaya dan Jasa pemandu wisata

Paket wisata dapat dipasarkan secara langsung oleh biro perjalanan wisata itu sendiri atau melalui perantara, yaitu agen perjalanan wisata dengan memberikan imbalan berupa komisi penjualan paket wisata yang terjual sesuai kesepakatan oleh kedua belah pihak. 
b. Pembentukan Desa Wisata

Desa wisata dapat menjadi salah satu daya tarik wisatawan lokal maupun mancanegara. Desa wisata ini dapat berupa desa adat ataupun desa Seni dan desa sentra penghasil kerajinan tangan.

Pembentukan desa wisata dapat dijadikan sebagai objek cultural Tourism yaitu salah satu jenis pariwisata yang disebabkan adanya daya tarik seni dan budaya di suatu daerah atau tempat seperti, peninggalan nenek moyang, benda-benda kuno, kesenian tradisional, serta upacara-upacara Adat yang khas dari wilayah tersebut contohnya, seperti wisata upaya ngaben di Bali, Pemakaman raja-raja di Toraja,

Pembentukan desa wisata ini juga dapat dijadikan sebagai sarana wisata edukasi yang bertujuan untuk menambah pengetahuan dan mengadakan penelitian dan mempelajari dari dekat kebudayaan setempat melalui objek wisata yang dikunjungi.

c. Pembentukan Jasa Informasi Kepariwisataan

Pembentukan jasa informasi kepariwisataan ini menjadi sarana penyedia informasi mengenai objek dan daya tarik wisata dari suatu wilayah yang dipromosikan juga menyediakan informasi-informasi lain yang diperlukan oleh wisatawan yang akan berkunjung ke daerah wisata tersebut.

Penyebaran informasi tentang usaha pariwisata ataupun tentang tempat-tempat wisata yang menarik di suatu daerah dapat melalui media cetak, media elektronik ataupun media komunikasi lainnya.

Jasa informasi kepariwisataan ini dapat berisi tentang informasi akomodasi, restoran, penerbangan, angkutan darat, angkutan laut, dan jasa layanan pemesanan. Selain itu, penyedia jasa informasi kepariwisataan bertanggung jawab atas kebenaran informasi kepariwisataan yang disediakan.

\section{Metode Penelitian}

\section{Jenis Penelitian}

Jenis penelitian dalam penelitian ini adalah kualitatif dengan pendekatan studi literatur dengan sumber data yaitu data sekunder yang diperoleh dari penelitian-penelitian terdahulu, dan sumber referensi lainnya. Studi literatur adalah cara yang dipakai untuk menghimpun data-data atau sumber-sumber yang berhubungan dengan topik yang diangkat dalam suatu penelitian yang didapat dari berbagai sumber, jurnal, buku dokumentasi, internet dan pustaka.Penelitian ini memberikan gambaran secara diskriptif tentang faktor penghambat implementasi pariwisata syari'ah di Bangkalan sekaligus berupaya menemukan solusi praktis menyelesaikannya mengingat Madura memiliki potensi yang cukup besar.

\section{Jenis Data}

Jenis data dalam penelitian ini menggunakan data sekunder. Data sekunder adalah sumber data yang tidak langsung memberikan data kepada pengumpul data. Data 
sekunder ini merupakan data yang sifatnya mendukung keperluan data primer seperti bukubuku, penelitian-penelitian sebelunya dan berbagai sumber bacaan yang berkaitan dengan zakat dan pengentasan kemiskinan.

\section{Metode Pengumpulan Data}

Metode pengumpulan data yang digunakan dalam penelitian ini menggunakan teknik triangulasi teori (Theory Triangulation). Data atau informasi dari satu pihak diperiksa kebenarannya dengan cara memperoleh informasi dari sumber lain. Tujuannya adalah membandingkan informasi tentang hal yang sama yang diperoleh dari berbagai referensi dan literatur agar ada jaminan tingkat kepercayaannya.

\section{Metode Analisis Data}

Metode analisis data yaitu teknik analisis data deskriptif kualitatif yaitu dengan datadata yang diperoleh dari tinjauan literatur serta website terkait disusun menjadi sebuah faktafakta yang aktual untuk kemudian dilakukan pembahasan.

\section{Pembahasan}

\section{Potensi Pariwisata Bangkalan}

Undang-undang No. 10/2009 tentang Kepariwisataan memberikan uraian, yang dimaksud dengan pariwisata adalah berbagai macam kegiatan wisata yang didukung oleh berbagai fasilitas serta layanan yang disediakan masyarakat, pengusaha, Pemerintah dan Pemerintah Daerah.

WTO (World Tourism Organization), pariwisata adalah aktifitas orang bepergian dan singgah di tempat jauh dari lingkungan mereka selama tidak lebih dari setahun berturut-turut dengan tujuan bersenang-senang, bisnis dan tujuan lain yang tak terkait kegiatan mencari uang di tempat yang dikunjungi. Merujuk kedua pengertian pariwisatadi atas, yang dimaksud dengan pariwisata syari'ah adalah berbagai macam kegiatan wisata yang didukung oleh berbagai fasilitas serta layanan yang disediakan masyarakat, pengusaha, dan pemerintah yang memenuhi ketentuan syari'ah. Selanjutnya, Hasil penelitian Master Card \& Crescent Rating tentang “Global Muslim Travel Index 2017”, posisi Indonesia saat ini berada diposisi ketiga negara konferensi Islam yang banyak dikunjungi wisatawan muslim dunia (Rasyid, 2017).

Kabupaten Bangkalan memiliki potensi destinasi yang sangat indah, menarik, unik dan luar biasa dan tidak kalah jika dibandingkan dengan daerah lain yang ada di Indonesia seperti NTB, banyuwangi dan lain lain. Jika diklasifikasi destinasi tersebut dapat dikelompokkan yang terdiri dari : tempat wisata alam (Bukit jaddih, Bukit kapur Arosbaya, pantai rongkang, Sembilangan, dll) wisata kuliner (bebek sinjay, matus, nasi serpang, dll), tempat wisata yang bernuansa religi (makam syaikhona Muhammad Kholil, Sultan Abdul Kadirun, Ratu Ibu, dll), wisata sejarah, sentra batik, wisata budaya dan wisata bahari.

Untuk lebih mudah dalam telaah potensi wisata bangkalan, berikut sajikan dalam bentuk tabel (Arifin, 2017): 
Tabel 1

Destinasi Wisata Bangkalan

\begin{tabular}{llll}
\hline No & Jenis Wisata & Obyek Wisata & Lokasi \\
\hline $\mathbf{1}$ & Wisata Alam & Pantai Manaron & Sepulu \\
& & Pantai Siring Kemuning & Tanjung Bumi \\
& Pantai Rongkang & Kwanyar \\
& Gua Bintang & Bangkalan \\
& Wana Wisata Gunung & Geger \\
& Geger & \\
& Bukit kapur Arosbaya & Arosbaya \\
& Bukit pelalangan & Arosbaya \\
& Bukit Jaddih & Socah \\
& Karapan Sapi & Tersebar \\
\multirow{5}{*}{ Wisata budaya dan } & Makam Syaikhona Kholil & Bangkalan \\
& & Makam Air mata Ratu Ibu & Arosbaya \\
& Menara Mercusuar Belanda & Socah \\
& Klenteng Cina & Bangkalan \\
& Seni Bahhong & Geger \\
& Museum Purbakala & Bangkalan \\
& Wisata Minat Khusus & Agrowisata kebun Jambu & Tersebar \\
& Agrowisata kebun salak & Tersebar \\
& Batik Tulis Madura & Tersebar \\
& Galangan kapal Tradisional & Tanjung Bumi \\
\hline
\end{tabular}

Tahun 2016 melalui Dewan Perwakilan Rakyat Komisi D, Bangkalan sempat diusulkan menjadi destinasi Pariwisata syari'ah ("Bangkalan Diusulkan Beralih ke Pariwisata Syariah - Nasional Tempo.co," 2016), namun sampai 2018 penerapan pasriwisata syari'ah belum kelihatan. Di tempat lain yang memiliki destinasi yang sama, missal Banyuwangi dan NTB sudah mencoba menerapkan Pariwisata syari'ah dan hasilnya mengalami peningkatan visitor cukup signifikan yakni lebih dari dari 50\% ("Lombok, Destinasi Wisata Halal Terfavorit di Dunia," n.d.).

\section{Membaca Faktor Penghambat}

Berdasarkan hasil penelitian yang dilakukan di instansi Pemda Dinas Pariwisata, DPRD komisi D, MUI Bangkalan, dan beberapa pengelola pariwisata, berikut akan disajikan faktor penghambat penerapan pariwisata halal di Bangkalan :

1) Kurangnya kerjasama antar pihak pemangku kebijakan. Ulama dan Tokoh masyarakat sebagian masih khawatir belum bisa menerapkan aturan syari'ah atau halal seratus persen, 
apalagi wisata pantai. Adanya pariwisata justru menjadi pemicuh tersedianya tempatHal ini mempengaruhi pemegang kebijakan bergerak cepat menentukan regulasi.

Sebagaimana informasi yang disampaikan oleh anggota Dewan komisi D, Bapak Mahrus, Rancangan atau draft perda Pariwisata halal sudah ada, sudah dirumuskan oleh anggota komisi, namun pengesahan oleh pemda butuh dukungan banyak pihak. Selain pemda, DPRD, MUI, dan pengelolah pariwisata, masyarakat sekitar juga memberi peranan signifikan terhadapat pertumbuhan dan perkembangan pariwisata halal. Kesadaran masyarakat akan memberikan keamanan dan kenyamanan bagi pengunjung. Kenyamanan akan menjadi iklan bagi msayarakata yang lain. Dengan demikian akan menambah daya pikat tersendiri.

2) Regulasi atau pergantian jabatan kepemimpinan pada birokrasi. Pergantian pada pos jabatan tertentu juga menjadi penyebab lambatnya implementasi pariwisata halal. Karena pejabat yang baru akan mempelajari renstra yang telah ada terlebih dahulu dan tidak bisa membuat kebijakan yang baru. Pergantian atau mutasi jabatan memang menjadi isu general di berbagai daerah, mengingat otonomi daerah memberikan kewenangan pemerintah Daerah. Sebagaimana kita fahami bersama bahwa birokrasi menuntut perencanaan yang matang bahkan jangkah panjang. Jika mutasi terjadi di pertengahan tahun, maka pemimpin dinas pariwisata yang baru tentu tidak bisa membuat kebijakan, hanya melanjutkan perencaan pemimpin sebelumnya.

3) Minimnya anggaran PEMDA untuk pengembangan pariwisata. APBD Bangkalan masih belum cukup mendukung untuk pengembangan pariwisata di Bangkalan. Anggaran yang disediakan masih cukup minim dibandingkan kegiatan atau pengembangan yang lain. Hal ini akan berdampak secara signifikan pada insfrastruktur, pengelolaan, dan pemasaran. Diantara ruh suksesnya program kerja dan kebijakan adalah dukungan anggaran, tanpa anggaran maka tidak mungkin program berjalan.

4) Belum adanya destinasi wisata andalan di Bangkalan. Beberapa destinasi wisata Bangkalan belum ada yang bisa diandalkan. Hampir semua yang dimiliki Bangkalan masih sama belum ada yang unggul hal ini akan mempengaruhi investor enggan membantu secara optimal.

5) Objek wisata masih milik perorangan bukan milik pemerintah. Beberapa destinasi wisata di Bangkalan berada di lahan milik pribadi warga. Kepemilikan pribadi tentu akan menjadi penghalang pengembangan.

6) Belum adanya aturan detil tentang pariwisata syari'ah atau halal dari kementerian pariwisata.

Pihak Dinas Pariwisata merasa belum mendapat juknis detil terkait pariwisata halal.

Hal ini tentu berpengaruh pada langkah strategis Dinas Pariwisata Bangkalan. Menurut Undang-undang No. 10/2009 tentang Kepariwisataan, yang dimaksud dengan pariwisata 
adalah berbagai macam kegiatan wisata yang didukung oleb berbagai fasilitas serta layanan yang disediakan masyarakat, pengusaha, Pemerintah dan Pemerintah Daerah.

Menurut WTO (World Tourism Organization), pariwisata adalah aktifitas orang bepergian dan singgah di tempat jauh dari lingkungan mereka selama tidak lebih dari setahun berturut-turut dengan tujuan bersenang-senang, bisnis dan tujuan lain yang tak terkait kegiatan mencari uang di tempat yang dikunjungi. Yang dimaksud dengan pariwisata syari'ah adalah berbagai macam kegiatan wisata yang didukung oleh berbagai fasilitas serta layanan yang disediakan masyarakat, pengusaha, dan pemerintah yang memenuhi ketentuan syari'ah.

Berbagai instansi seperti MUI, DPRD dan juga pengelola pariwisata sudah sangat antusias dengan penerapan pariwisata Halal, harapannya hal ini akan berdampak signifikan pada pertumbuhan perekonomian. Beberapa hal sudah dilakukan oleh instansi terkait, seperti DPRD sudah merumuskan draft perda Pariwisata halal di bangkalan. Dari pihak MUI sudah sering mengarahkan realisasi perda Pariwisata halal segera diberlakukan. Namun MUI hanya bisa mengarahkan selebihnya pihak PEMKAB Bangkalan yang harus bisa mengeksekusi rencana tersebut Solusi yang harus di lakukan untuk menerapkan pariwisata halal di bangkalan dengan merumuskan bersama stake holder serta perlunya akademisi dan perguruan tinggi dalam proses pengembangan.

\section{Kesimpulan}

Dari hasil penelitian yang telah dilakukan dapat disimpulkan beberapa hal yaitu Faktor penghambat implementasi pariwisata halal di bangkalan antara lain: Kurangnya kerjasama antar pihak pemegang kebijakan, regulasi atau pergantian pimpinan dalam instansi, minimnya anggaran pemda untuk pariwisata, belum adanya destinasi unggulan, destinasi masih milik perorangan bukan milik pemda, belum adanya aturan detil tentang pariwisata syari'ah atau halal dari kementerian pariwisata.

Solusi mengatasi hambatan tersebut antara lain, stake holder semuanya mendukung termasuk perguruan Tinggi dan masyarakat selaku pengguna jasa pariwisata, perda segera disakan, dan mengoptimalkan sosialisasi.

Dari kesimpulan diatas, beberapa instansi sudah memiliki keinginan kuat terhadap berlakunya pariwisata halal, sekiranya ada yang menginisiasi semua pemegang kebijakan berkumpul di satu forum dan juga melibatkan pemprov, kemudian kesepakatan mendorong disahkannya perda, hal ini akan mempercepat implementasi pariwisata halal di Bangkalan.

\section{Daftar Pustaka}

Ahmad Badarus Syamsi, Analisis Potensi Wisata di Bangkalan yang Sesuai dengan Syariah yang Menunjang Jawa Timur Sebagai Salah Satu Destinasi Pariwisata Syariah, Prosiding Seminar Nasional dan Call For Papers UTM. Madura, 30 Nopember 2016

Arifin, S. (2017). Digitalisasi Pariwisata Madura. Jurnal Komunikasi. 
https://doi.org/10.21107/ilkom.v11i1.2835

Bangkalan Diusulkan Beralih ke Pariwisata Syariah - Nasional Tempo.co. (2016). Retrieved February 27, 2020, from Nasional Tempo website: https://googleweblight.com/i?u=https:// nasional.tempo.co/read/751623/bangkalandiusulkan-beralih-ke-pariwisata-syariah\&hl=id-ID

Lombok, Destinasi Wisata Halal Terfavorit di Dunia. (n.d.). Retrieved February 27, 2020, from https://www.cnbcindonesia.com/syariah/20180412114337-29-10722/lombokdestinasi-wisata-halal-terfavorit-di-dunia

Muljadi, \& Warman, A. (2016). Kepariwisataan dan Perjalanan. Jakarta: Rajawali Pers.

Prasetyo, A., \& Arifin, M. Z. (2018). Pengelolaan Destinasi Wisata Yang Berkelanjutan Dengan Sistem Indikator Pariwisata. Jakarta: Indocamp.

Rasyid, A. (2017). Peluang dan Tantangan Wisata Halal di Indonesia. Retrieved November 18, 2017, from bussines-law.binus.ac.id

Shofiyun Nahidloh, Potensi Pariwisata Islami di Kabupaten Bangkalan Madura, Prosiding Seminar Nasional dan Call For Papers UTM. Madura, 30 Nopember 2016

Zahro, A. (2013). Konsep Wisata Syari'ah. Forum FGD Unipdu Jombang. Jombang.

Undang-undang No. 10 Tahun 2009 tentang Kepariwisataan

UU Republik Indonesia Nomor 9 Tahun 1990 